\title{
Research Article \\ Digital Transformation and its Implications on Organizational Behavior
}

\author{
Ulrike Stefanie Foerster-Metz ,Katrin Marquardt, Nina Golowko, Andreas Kompalla \\ and Christian Hell
}

The Bucharest University of Economic Studies, Bucharest, Romania

Correspondence should be addressed to: Ulrike Stefanie Foerster-Metz; ulrike.s.foerster@web.de

Received date: 6 September 2017; Accepted date: 22 January 2018; Published date: 14 May 2018

Academic Editor: Janusz Wielki

Copyright (C 2018. Ulrike Stefanie Foerster-Metz ,Katrin Marquardt, Nina Golowko, Andreas Kompalla and Christian Hell. Distributed under Creative Commons CC-BY 4.0

\begin{abstract}
Digital Technologies such as advanced algorithms, robotics, and analytics amongst others are transforming the dynamics of the workforce within enterprises. Therefore, the authors of this work have reviewed the implications of rising technologies on Organizational Behavior. Many of the current studies on this theme have focused on the technological side and understudied the holistic point of view and its implications on organizational behavior. The novelty of this work relies on providing an understanding of the most important digital technologies and reviewing their effects on employees and leadership. For this purpose, and based on the actuality of the topic, the authors decided to analyze the impacts of digital technologies on organizational behavior by providing a literature review and structuring it by technology and implication. The article is structured in three parts: first of all the definition of Organizational Behavior and digitalization were reviewed to establish a theoretical framework, followed by the analysis of the impacts and effects of the digitalization on leadership and employees, and finally the findings were summarized in a structured scheme.
\end{abstract}

Keywords: Organizational Behavior, Digitalization, Leadership, Employee

\section{Introduction}

Against the backdrop of digitalization, globalization, demographic changes and shortage of resources, it is important for companies to understand the impacts and effects associated with these mega trends and to prepare themselves for the future. Due to new technologies, algorithms, interconnectedness and big data storage, the world is becoming more and more digitalized and transparent for all stakeholders. It is no longer only about a

Cite this Article as: Ulrike Stefanie Foerster-Metz ,Katrin Marquardt, Nina Golowko, Andreas Kompalla and Christian Hell (2018)," Digital Transformation and its Implications on Organizational Behavior " Journal of EU Research in Business , Vol. 2018 (2018), Article ID 340873, DOI: 10.5171/2018.340873 
marketing strategy to influence consumers, company branding to retain employees or to identify ways to improve processes or automate the manufacturing. Nowadays not only the integration and utilization of innovative technologies and business models matter, it is essential to understand the interdependencies and impacts on the fundamentals of organizational behavior, namely, the interaction between the two determinants; technology and people. Therefore, and because of the actuality of the topics, the authors decided to investigate and summarize the impacts and effects of the digitalization on leadership and workforce to proactively manage the necessary change to ensure the companies sustainability and to maintain or extend their position in the market. The study starts by understanding Organizational Behavior theory, then followed by summarizing the technology brought up by digitalization and ending with combining this with the impact on leadership and workforce.
In literature, we can find extensive definitions of the study of Organizational Behavior, however, for the purpose of this paper, the authors will use the definition of DuBrin (2002, pp.3-4) who describes Organizational Behavior as the systematic approach to understand the behavior of individuals within organizations. Starting from individuals; as the smallest entity of study, to big organizations and their interaction with the environment. In addition, it is important to understand the interrelations of human behavior with other variables such as technology which together cover the whole organization (Mullins, 1990). In literature, three major factors can be found that affect Organizational Behavior. These are people, structure and technology which constantly interact with the environment that surrounds them within and outside an organization. (Richards, 2017) Figure 1 describes the factors and the interaction within an organization.

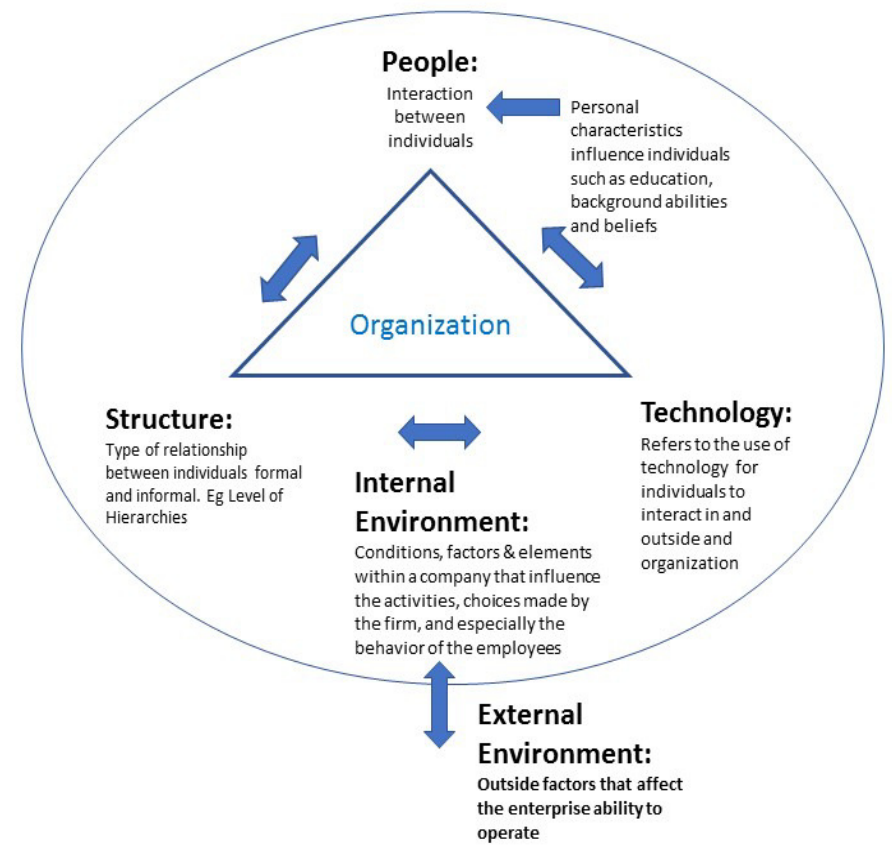

Figure 1: Factors affecting Organizational Behavior

Source: Authors own contribution based on Richards (2017)

Ulrike Stefanie Foerster-Metz ,Katrin Marquardt, Nina Golowko, Andreas Kompalla and Christian Hell (2018), Journal of EU Research in Business, DOI: 10.5171/2018.340873 
The influence of technology on work environments and workflows is an important determinant of Organizational Behavior science, as changes in technology may not only affect the individual characteristics of the workforce, but as well the organizational structure of enterprises. The way technology is implemented or used within a company may affect the company's inner culture as well as their behavior towards stakeholders. Furthermore, the implementation of modern technology may bring along a gradual change in the composition of the workforce. For example, younger, better educated, more mobile as well as more technologically versed generations will enter companies in greater numbers as in the past, resulting in a changeover within organizations that may as well bring along a new set of values, attitudes and concerns that affect the Organizational Behavior within companies (DuBrin, 2002).

\section{Understanding the Meaning of Digitalization}

Over the last decades, the digitalization and interconnectedness have shifted the economy from a mainly physical to a software controlled economy and the information technology has become a fundamental part of our industry and society. In this context, buzzwords like digitalization, Internet of Things (IoT), big data, robotics, automation, mobility and others are ubiquitous; they are discussed in social media, by politics and economy. But what do these terms mean?, how are they interlinked with each other? and in which ways do they change our whole work and life environment?

The omnipresence of the words digitalization and digital transformation and their obvious interconnection to all the other terms, induced the authors to have a closer look to their definitions, characteristics and impact on society and economy. According to Ernst \& Young (2011) Digitization means the conversion of analogue information to digital (computer-readable) information. From the middle of the $20^{\text {th }}$ century onwards, after the invention of the transistor and microprocessor the technologies of digitization enabled the conversion of traditional media such as picture, paper, sound, video or signal into bits and bytes (ones and zeros) of computer storage (Press, 2015). Since the beginning of the 21st century, with the emergence of social media, social networks and by the improvement of the sensor technology, additional information is being recorded, digitalized and shared such as social life activities and physical data of life like location, temperature, force, weight, blood pressure and stress. Today, non-digitalized products are more and more digitalized as they receive, for example, tracking sensors to locate them or network connections to deliver status information. The numbers published by BMWi (2016) show that the amount of digital information has increased dramatically, in 1993, it was just $3 \%$ and in 2007 , it reached already $94 \%$ of the worldwide information (see also figure no 2). 


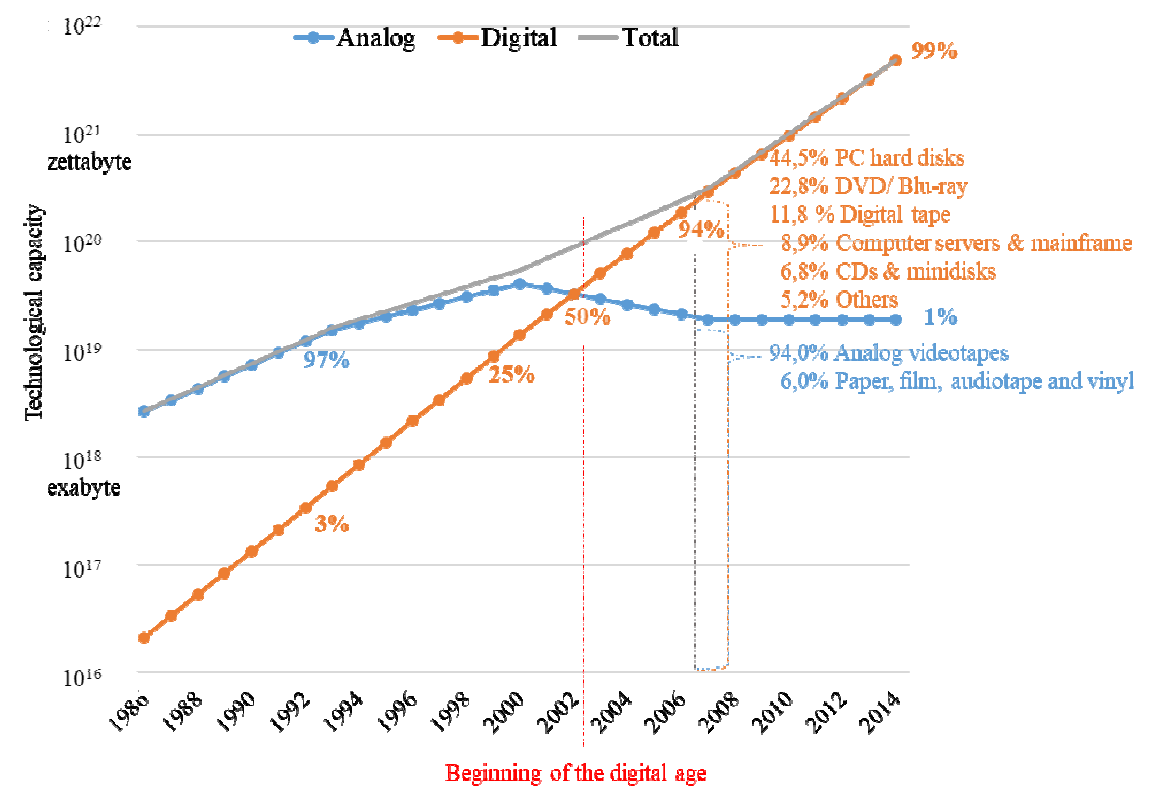

Figure 2: Development of the global information storage capacity

Source: Authors design based on Hilbert (2015)

The last years have shown that the digital transformation of economic processes and transactions and human interactions became an inescapable megatrend in ways never been anticipated years ago, and it is still the beginning. This growing dependence on the ubiquitous technologies and solutions combined with the demographic changes, declining availability of resources, globalization of the markets and growing international competition, and the increasing customer demands request new ways of thinking and acting to identify and deal with the related opportunities and challenges (Marquardt, 2017).

To provide an overview and to gain a common understanding, the authors have summarized in table number 1 the most significant digital technologies and solutions, their meaning and added some examples. 
Table 1: Overview digital technologies

\begin{tabular}{|c|c|}
\hline TECHNOLOGY & EXPLANATION / EXAMPLES \\
\hline \multicolumn{2}{|r|}{ INTERCONNECTEDNESS \& AVAILABILITY } \\
\hline $\begin{array}{l}\text { MOBILE } \\
\text { IOT } \\
\text { CLOUD } \\
\text { (COMPUTING) }\end{array}$ & $\begin{array}{l}\text { Mobile is the generic term for cellular communication and mobile } \\
\text { computing with wireless networking / Smartphone, tablet, laptop } \\
\text { IoT is the connection from on and off switchable devices to the } \\
\text { internet. They get a virtual presence and can connect to other objects } \\
\text { and database data (Morgan, 2016) } \\
\text { Cloud is the provisioning of IT infrastructure (e.g., networks, servers, } \\
\text { storage, applications, services) over the internet on demand / } \\
\text { Software-as-a-Service (SaaS), Platform-as-a-Service (PaaS), } \\
\text { Infrastructure-as-a-Service (IaaS) }\end{array}$ \\
\hline \multicolumn{2}{|r|}{ INFORMATION \& INTELLIGENCE } \\
\hline $\begin{array}{l}\text { BIG DATA \& } \\
\text { ANALYTICS }\end{array}$ & $\begin{array}{l}\text { Big Data is the synonym for vast and complex data volumes which } \\
\text { differs by their size, diversity and rapid pace of change (Plattner, } \\
2016 \text { ) } \\
\text { Analytics is the process of examining Big data to uncover patterns, } \\
\text { correlations, market trends, customer preferences and other useful } \\
\text { information (Rouse, } 2017 \text { a) }\end{array}$ \\
\hline \multicolumn{2}{|r|}{ AUTOMATION \& EFFICIENCY } \\
\hline $\begin{array}{l}\text { ROBOTICS } \\
\text { AUTOMATION } \\
\text { ROBOT PROCESS } \\
\text { AUTOMATION } \\
\text { (RPA) } \\
\text { INTELLIGENT } \\
\text { AUTOMATION } \\
\text { (IA) } \\
\text { ARTIFICIAL } \\
\text { INTELLIGENCE } \\
\text { (AI) }\end{array}$ & $\begin{array}{l}\text { Robotics is the interdisciplinary branch of engineering and science } \\
\text { that deals with the design, construction, operation, and use of robots } \\
\text { (Rouse, 2017b) } \\
\text { Automation is the technique of making a machine, a process, or a } \\
\text { system to be operated automatically with no or reduced human } \\
\text { intervention. It can be done by various means like mechanical, } \\
\text { hydraulic, pneumatic, electrical, electronic devices and computers } \\
\text { (ISA, n.d.) } \\
\text { Robot Process Automation is the fully automated processing of } \\
\text { structured business processes (repeatable and predictable } \\
\text { interactions) by software robots or by using artificial intelligence (AI) } \\
\text { Intelligent Automation is a nascent and high cost technology which } \\
\text { enables automating non-routine tasks such as those involving } \\
\text { intuition, judgement, creativity, problem solving, etc. based on } \\
\text { dynamic information (Deloitte, 2017) } \\
\text { Artificial Intelligence is part of computer science bringing human } \\
\text { capabilities and characteristics to machines like understanding } \\
\text { language, learning, reasoning, solving problems, etc. (McKinsey, 2017) } \\
\text { / } \\
\text { Digital assistant Siri, Alexa, Cortana or Echo }\end{array}$ \\
\hline \multicolumn{2}{|r|}{ COMMUNICATION \& COLLABORATION } \\
\hline SOCIAL (MEDIA) & $\begin{array}{l}\text { is the collection of online communications channels dedicated to } \\
\text { community-based input, interaction, content-sharing and } \\
\text { collaboration (Rouse, 2016a) / Facebook, Twitter, Instagram, } \\
\text { Pinterest, Snapchat, YouTube }\end{array}$ \\
\hline \multicolumn{2}{|r|}{ PRIVACY \& SECURITY } \\
\hline
\end{tabular}

Ulrike Stefanie Foerster-Metz ,Katrin Marquardt, Nina Golowko, Andreas Kompalla and Christian Hell (2018), Journal of EU Research in Business, DOI: 10.5171/2018.340873 


\begin{tabular}{|l|l|}
\hline NEXT- \\
$\begin{array}{l}\text { GENERATION } \\
\text { SECURITY }\end{array}$ & $\begin{array}{l}\text { is a new generation of intelligent, highly scalable security products } \\
\text { and platforms which includes both cybersecurity and physical } \\
\text { security and with a more proactive and adaptive approach (Rouse, } \\
\text { 2016b) }\end{array}$ \\
\hline
\end{tabular}

Source: Authors' own research results/contribution

All the above listed technologies and solutions have and will have a growing and powerful effect on economy, environment and society. They provide new functionalities, increase productivity and efficiency, give higher flexibility and diversity and allow more reusability, parallelism and duplication. In addition, they will change the business models, production processes, the way of working and collaborating, will also permit more mobility, enable faster decision making and delivery, and support higher standardization, customization and prosperity. On the other side, they can also be related to negative impacts as such as unemployment, immiseration, pressure, always on mentality, ever-increasing exhaustion, despair, higher complexity and social isolation. Therefore, it is important to be aware of these impacts, whether they are positive or negative and to deal with them from the very first beginning. In this connection and interlinked with the digital transformation, terms like work 4.0, management 2.0, and leadership 4.0 came up and their meaning will be reviewed in this article.

\section{Modern Leadership and the Effects of The Digitalization}

Understanding how digitalization is affecting and changing leadership practices in organizations is essential because today digitization is taking place in almost all sectors of the economy at a very fast pace and in a very deep manner. From manufacturing, financial services, customer service, health, agriculture, retail and logistics all of these sectors are using big data, new technologies and solutions to drive their business forward and to survive on the highly competitive market. This does not only imply changes in the economy and work system, it also implies changes in leadership management, thinking and acting. To support this digital transformation, the company needs to shift from their traditional, hierarchical structure to a flexible, decentralized organization with a team/project-oriented leadership to keep pace with the complex and fast changing environment (digital-centric business) and the increasing customer requirements (customer-led market). Additionally, the generation change from the baby boomer to the digital natives (Generation $\mathrm{Y}$ and $\mathrm{Z}$ ), which have unique characteristics and capabilities in comparison to past generations, will require new working structures and leadership.

The new leadership, digital leadership or leadership 4.0 does not only mean the usage of the new digital media for collaboration and communication, but it also requires the adaption of the leadership strategies and methods to the digital reality. The future leader should be able to utilize the new technologies and solutions, to adapt himself fast to changes and manage them, to have a pioneer spirit and to be able to learn quickly. He should also be contextual, emotionally intelligent and trustworthy, and should lead democratically, share responsibilities, to be decisive and cooperative, control and promote networks, trust and motivate employees, and give them regular feedback (Sattler, 2016). From the author's viewpoint, the so-called VOPA leadership model (see figure no. 3) designed by Buhse (2014), combines all those characteristics and can be used as the basic model for the digital leadership by covering all the central elements for a successful corporate and management culture in the digital age and 
reflecting also the demands from the new generations.

The core of the digital leadership built on trust is not new because "trust" is one of the significant emotions in human relationships. The leader needs to trust in the management and the employees need to trust in the leader and vice versa, only then the right decisions can be made and the required actions can be taken within the time of increasing complexity, insecurity and speed. All the other four points are supporting the establishment and maintenance of trust.
Openness and transparency take away the fear and uncertainty and give a clear view and gain understanding. Participation and involvement give the possibility to actively engage, modify and assume accountability. Agility allows to react faster and context based and networking enables and support the sharing, collaborating and improving. Leaders need to have a direct and personal engagement with all employees, especially, to the new talents from the next generations because they are the incubators of change in the digitalized world (Ernst and Young, 2011).

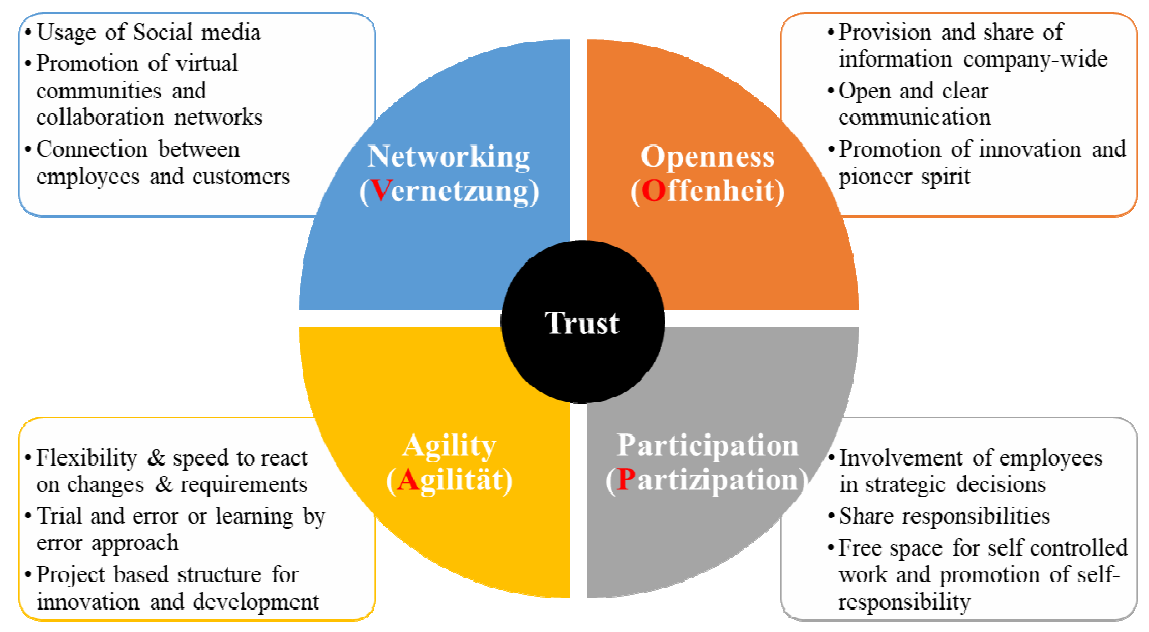

Figure 3: VOPA plus model for digital leadership

Source: Authors design based on Buhse (2014)

The new digital technologies and solutions are not just stimulating the need for change, they also enable and support the change itself. Here are some examples: big data in combination with learning algorithms enable organizations and leaders to better predict and control their processes and applications, allow them to optimize the work such as material flows, targeted marketing activities and evaluating employee's performance or tasks. Likewise, the integration of social media platforms can support the engagement with many more employees in distributed organizations as it was possible before with standard meeting structures. Here the leaders can share information, give regular updates, foster understanding and create conviction to the spread workforce at the same time. Furthermore, the usage of data-enabled talent-management systems (based on algorithmic data analysis) can rise the number of meaningfully evaluated 
employees against their knowledge and competencies, increase the precision of these evaluations and free up the leadership to concentrate on the personal relationship (Feser et al., 2017). But it must be kept in mind that the way technology takes over or interferes in some of the managerial activities also bares the risk of decreasing the creative adaption to a problem and the loss of the historical background and the organizations will be increasingly dependent on the providers of these new technologies as they most likely lack internal resources with the capability to program and run this system. Hence, it is important for the managers and leaders to analyze their business and market situation first, then to decide about the right strategy and structure and to involve their employees in the digital transformation.

\section{Impact of Digitalization on Employees}

The continuous change that the digitalization of things is bringing along is having a major impact on the workforce at various levels such as rationalization, knowledge, performance, efficiency, skill set, etc.. Hereafter, the authors summarized the impact based on an extended literature review.

Digital learning platforms can improve the company's internal education by hosting tailored trainings and development programs for employees and leaders, where they can attend the training in alignment with their work schedules, matched with their self-pacing and choice of topic. This new training methods support the acquisition of skills based on the strategies the organizations follow and which educational systems fail to deliver. However, this on the contrary, demands the employees to be able to continuously learn to be able to keep up with the advancements of technology and avoid rationalization in the long run (Gow and MacDonald, 2006).
Until now, the rationalization of workforce due to the new digitalized world has majorly affected those employees with low qualifications due to the automation of production processes. However, the advancements in intelligent automation and artificial intelligence start to cast a shadow over higher qualified resources. Having a formal qualification is no longer a guarantee for a lifelong secured career, this is due to the fast changes in technology that can no longer be secured by the educational system. Nowadays, specially endangered are those professions in which precision and routine make a high portion of the daily job activity as these can be more easily automated and replaced by computer algorithms such as sales agents in call centers, clerical workers, packers, pilots and even judges. Regarding latter ones, it is argued that they fight an unequal competition against autopilots and algorithms which can navigate flawlessly and are sly decision takers. On the other hand, jobs that require a higher amount of creativity and social intelligence as well as entrepreneurship, seem to be more sustainable (Rinne and Zimmermann, 2016). Due to the before mentioned the future of work based on a digitalized economy also requires a new skill set which will enforce a sustainable working future. As an example, the outsourcing industry has started to demand specific hard and soft skills to be related to the advancements in technology to be able to deliver added value services which will help to win the competition against artificial intelligence and algorithms (Foerster-Metz \& Golowko, 2017).

Within higher qualified jobs in the digitized world, a new working space is created that allows new collaborative working models due to cloud computing platforms. The software industry is one of the trendsetters regarding this working model which is based on agile development such as Scrum with principles of Lean Production. This new type of collaborative working on clouds permits quick development sprints which constantly and in real time allow managers $\backslash$ leaders to test the performance of each delivered work 
package. Furthermore, it enables them to take decisions and direct work at a higher speed as well as to make the work performance of each team member transparent. Consequently, each team gains more empowerment. It also shows the tendency of simple execution as in an "assembly line".

Due to the digitalized world, employees are no longer limited to work only from the office and for only one employer. This has brought changes in how workforce is being contracted. Many individuals chose today to work as digital freelancers so called "crowd worker" who can work from everywhere through mechanisms like clouds, skype, teleconferences, etc.. ${ }^{1}$ These offer their work and skills through virtual crowdsourcing platforms in which organizations can outsource and post specific work packages. Due to this flexible work organization and flexible work time models, home office and variable time schedules will continue to increase due to the limited availability of qualified workforce. Through this trend, entrepreneurial risks are shifted from employer to employee. Instead of strict work instructions, new civil arrangements come to place. Flat hierarchies, as well as performance based remuneration, gain more significance. Employees turn into entrepreneurs which consequently demands entrepreneurial thinking as a key competence for the future work market place. In addition, work compensation is reduced to work packages so that costs last for the time of an assignment and hidden cost reserves of permanent employees can be reduced. Through these virtual platforms, the workforce also turns global and is exposed to higher competition. On the downturn, these "employees" have no sense of affiliation to companies and therefore, higher effort is requested to motivate and engage them towards the values, vision and mission of companies. At the same time

\footnotetext{
${ }^{1}$ For a detailed description crowd worker consult Boeckler Impuls, 2016
}

contractors are not protected by syndicates or similar and do not have codetermination rights. They fall out of the labor law agreements as they are independent entrepreneurs. Furthermore, freelancers are not often integrated by law to the social security systems if the government has not foreseen any protection. (Rinne and Zimmermann, 2016; Staab and Nachtwey, 2016).

Performance surveillance has taken a new shape through the digitization of work steps for example, the logistics industry in which pickers hold a hand scanner enabled with cameras and microphones which are able to transfer movement data of the workforce. Companies can use this information to define performance profiles, measure and compare the performance of diverse workforce. In addition to having a performance surveillance, a high technical process control is enabled through this hand scanners as these provide the employees with consecutive work steps to maximize workflow efficiency. This results in an almost gapless system automation reducing the workforce autonomy to structure their work place and creativity for innovative solutions. This trend can also be found in higher qualified jobs such as developers, sales agents and analysts within the tertiary sector. This is possible through individualized performance review based on analysis of big data and control related software. For example, through the analysis of big data, it is possible to determine if a sales man had ordered enough products for a specific selling period as well as to analyze how many client contacts have been realized and what was the duration and outcome of the meeting (Staab and Nachtwey, 2016; Boes et al, 2016). Performance measure trough target setting becomes also a new dimension as companies start to use mobile apps with their employees in which these can document target accomplishments on daily basis. These apps create an elevated level of transparency as they allow making the individual performance transparent to everyone in the company. Platforms like 
Twitter allow "following" colleagues and informing them about alterations in their work activities. As a result, communities can be used to track, measure and influence the social behavior of employees.

Dissolution of boundaries regarding time and work place started in the 80s with telework possibilities. In course of the years, due to the increased digitalization of work through the possibility of taking work everywhere with smartphones, tablets and laptops, work has become a constant companion in many countries and especially for higher qualified jobs. It has become a normality to work on weekends, vacations, trains and airplanes, etc.. However, still not all companies allow their employees to make use of these possibilities because despite the advanced possibilities of performance surveillance, they fear not to have enough control over their employees and the expected work results. On the other hand, those employees that are enabled to use these work technologies started complaining about the higher expectations of constant reachability. In this case, again some EU countries are struggling to find the right labor law mix that will cope with this new work environments. At the same time, flexible and boundary free work requires from the individuals a high level of selforganization and time management. (Carstensen, 2016).

Company information which in the past was only accessible to higher leadership - as it often implied higher printing and informational costs - can now be shared with employees through diverse digital technology like sharing platforms, chatting rooms, intranets, etc.. This allows employees to have a higher awareness about the company and its activities permitting organizations to become more transparent and open towards employees. Because of greater transparency improvements in decision-making, employee confidence and internal networking have been achieved (Francis and Scheers, 2013). However increased transparency implies new code of conducts that will protect information from leaking (Schildt, 2017).

In addition, companies need to deal with the fact that the increased digitization of information generates informed employees, consumers and partners that have real time access to competitive pricing and product information which increases pricing transparency. Digital platforms allow peer recommendations by consumers which can be on the one hand freighting as they put major pressure on the control of the branding message and on the other hand, it gives the opportunity for employees to engage with consumers as ambassadors for the brand. Latter ones are called "prosumers". In this sense, a new two-way communication has been enabled between consumer and brand which bares opportunities and risks. New collaborative approaches towards stakeholders are required to keep the engagement up. Companies have started to use this new digital communication to test in communities' innovations and to receive and provide feedback on issues of problems with products, etc.. However, this active communication with the stakeholders also requires a new way of thinking and culture within organizations that is more than ever a service oriented (Ernst and Young, 2011).

\section{Conclusion}

Cloud computing, advanced algorithms, and artificial intelligence are all interrelated and have a major effect on how individuals are changing their way of acting within and outside organizations. The digitalization has shown that it has majorly changed the workforce population, the skill set needed, and the way to interact and collaborate as well as to communicate within an organization not only from employee's side but also from the leadership side. Table 2 provides a summary of how each nascent technology is having an impact on the factor people within an organization. 
Table 2: Summary of Findings

\begin{tabular}{|c|c|c|}
\hline TECHNOLOGY & IMPACT ON WORKFORCE & IMPACT ON LEADERSHIP \\
\hline \multicolumn{3}{|c|}{ INTERCONNECTEDNESS \& AVAILABILITY } \\
\hline $\begin{array}{l}\text { MOBILE } \\
\text { IOT } \\
\text { CLOUD }\end{array}$ & $\begin{array}{l}\text { - Changes in contracting } \\
\text { form of Workforce: Crowd sourcing } \\
\bullet \quad \text { Flexible work models in } \\
\text { time and space } \\
\bullet \quad \text { Free space of self- } \\
\text { controlled work } \\
\bullet \quad \text { Entrepreneurship and } \\
\text { empowerment at the risk of simple } \\
\text { execution } \\
\bullet \quad \text { Exposure to higher global } \\
\text { workforce competition } \\
\bullet \quad \text { Reduction of sense of } \\
\text { affiliation of the workforce } \\
\bullet \quad \text { Lose of social security } \\
\text { protection }\end{array}$ & $\begin{array}{l}- \\
\text { - Flat Hierarchies } \\
\text { decision taking } \\
\text { - Enforces collaborative } \\
\text { approach } \\
\text { of employees due to the } \\
\text { externalization of work packages } \\
\text { and personal distance to the } \\
\text { contractor } \\
\text { importance as managers can cover } \\
\text { larger departments and locations }\end{array}$ \\
\hline \multicolumn{3}{|c|}{ INFORMATION \& INTELLIGENCE } \\
\hline $\begin{array}{l}\text { BIG DATA \& } \\
\text { ANALYTICS }\end{array}$ & $\begin{array}{l}\bullet \quad \text { Higher performance } \\
\text { surveillance } \\
\bullet \quad \text { Loss of creativity due to } \\
\text { higher and detailed process } \\
\text { structure } \\
\bullet \quad \text { Higher amount of } \\
\text { performance based remuneration }\end{array}$ & $\begin{array}{l}\text { Optimization of processes } \\
\text { - Increased evaluation of } \\
\text { employees, frees up management } \\
\text { from their surveillance role as } \\
\text { analytics start to take over the } \\
\text { decision } \\
\text { due to lack of programming } \\
\text { knowledge }\end{array}$ \\
\hline \multicolumn{3}{|c|}{ AUTOMATION \& EFFICIENCY } \\
\hline $\begin{array}{l}\text { ROBOTICS } \\
\text { AUTOMATION } \\
\text { ROBOT PROCESS } \\
\text { AUTOMATION } \\
\text { INTELLIGENT } \\
\text { AUTOMATION } \\
\text { ARTIFICAL } \\
\text { INTELLIGENCE } \\
\end{array}$ & $\begin{array}{l}\text { - Rationalization of } \\
\text { workforce for higher qualified and } \\
\text { lower qualified jobs } \\
\text { • Reduction of workforce } \\
\text { autonomy, creativity and } \\
\text { innovation }\end{array}$ & $\begin{array}{l}-\quad \text { Level of hierarchies } \\
\text { becomes flat } \\
\text { - Loss of creative adaption to } \\
\text { problems and historical background }\end{array}$ \\
\hline \multicolumn{3}{|c|}{ COMMUNICATION \& COLLABORATION } \\
\hline SOCIAL MEDIA & $\begin{array}{ll}\bullet & \text { Transparency } \\
- & \text { Knowledgeable workforce } \\
- & \text { Increased need for service } \\
\text { orientation toward client } \\
\bullet \quad \text { Enforces collaboration and } \\
\text { knowledge sharing } \\
\end{array}$ & $\begin{array}{l}\text { - Demand for collaborative } \\
\text { and transparent leadership } \\
\text { - Open and clear } \\
\text { communication } \\
\text { information company wide at low } \\
\text { inform }\end{array}$ \\
\hline
\end{tabular}

Ulrike Stefanie Foerster-Metz ,Katrin Marquardt, Nina Golowko, Andreas Kompalla and Christian Hell (2018), Journal of EU Research in Business, DOI: 10.5171/2018.340873 


\begin{tabular}{|c|c|c|}
\hline & & $\begin{array}{ll}\text { cost } & \\
\bullet & \text { Enforcement of engagement } \\
\bullet & \text { Influence social behavior of } \\
\text { employees }\end{array}$ \\
\hline \multicolumn{3}{|c|}{ PRIVACY \& SECURITY } \\
\hline $\begin{array}{l}\text { NEXT- } \\
\text { GENERATION } \\
\text { SECURITY }\end{array}$ & $\begin{array}{l}\text { - Risk of leakage of personal } \\
\text { employee data }\end{array}$ & $\begin{array}{l}\text { Development of new codes } \\
\text { of conduct }\end{array}$ \\
\hline
\end{tabular}

Source: Authors' own research results/contribution

Through the authors' analysis, it has become clear that the workforce of tomorrow will have to think and act interconnected and will need to focus on innovation and creativity to be able to cope with structural changes technological development has brought along. Questions are still open such as at what pace will further rationalization take place?, and what efforts are being undertaken by the environment to get along with the skill need of rationalized workforce?.

\section{References}

1. Anon., (2016): Die digitalen Tageloehner, Boeckler Impuls [online], Available at: <https://www.boeckler.de/64443_64455.ht $\mathrm{m}>$, [Accessed: 31.08.2017].

2. Boes, A. and Kämpf, T., (2016): Digitalisierung und "Wissenarbeit", Aus Politik und Zeitgeschichte, (66/18-19), pp. 32-39.

3. Buhse, W., (2014): Management by Internet: Neue Führungsmodelle für Unternehmen in Zeiten der digitalen Transformation. Kulmbach: Börsenmedien AG. ISBN: 978-3864701726.

4. Carstensen, T., (2016): Ambivalenzen digitaler Kommunikation am Arbeitsplatz, Aus Politik und Zeitgeschichte, (66/18-19), pp 39-46.

5. DuBrin, A.J., (2002): Fundamentals of Organizational Behavior An Applied
Perspective, $2^{\text {nd }}$ ed. New Yoork: Pergamon Press Inc..

6. Feser, C., Nielsen, N., Rennie, M., (2017): What's missing in leadership development? [online] Available at: <http://www.mckinsey.com/globalthemes/leadership/whats-missing-inleadership-development> [Accessed 04.08.2017].

7. Förster-Metz, U.S. and Golowko, N., (2017): Employability skills for the Romanian Outsourcing Industry, In: 2017 The 11th international Conference on business excellence - Strategy, Complexity and energy in changing times, March 30-31, Bucharest, Romania. ISBN: 978-606922992-7. pp. 259-260.

8. Francis, J. \& Scheers, C., (2013): The future workplace of young Europeans, European View, (12/2), pp 199-204.

9. Gow, K., \& McDonald, P., (2006): Attributes required of graduates for the future workplace. Journal of Vocational Education \& Training, 52, 373-396.

10.Hilbert, M., (2015): The World's Technological Capacity to Store, Communicate, and Compute Information. [online] Available at: <http://www.martinhilbert.net/WorldInfoC apacity.html/> [Accessed 27.07.2017].

11.Marquardt, K., (2017): Smart Services Characteristics, Challenges, Opportunities and Business Models. Proceedings of the 
International Conference on Business Excellence, 11(1), pp. 789-801. doi:10.1515/picbe-2017-0084.

12.Morgan, J., (2016): A Simple Explanation of 'The Internet of Things'. [online] Available at: <http://www.forbes.com/sites/jacobmorga $\mathrm{n} / 2014 / 05 / 13 /$ simple-explanationinternet-things-that-anyone-canunderstand $>$ [Accessed 28.07.2017].

13.Mullins, L. J., (1990): Management and Organizational Behaviour.2 ${ }^{\text {nd }}$ ed., London: Pitman Publishing.

14.Plattner, H., (2016): Big Data. [online] Available at: <http://www.enzyklopaedieder-wirtschafts-

informatik.de/lexikon/daten-

wissen/Datenmanagement/Datenmanageme nt--Konzepte-des/Big-Data> [Accessed 28.07.2017].

15.Petry, T., (2016): Erfolgreiches Führen im digitalen Zeitalter. [pdf] Available at: $<$ https://

www.izgs.de/app/download/13864564096 /thorsten petry erfolgreiches führen.pdf> [Accessed 03.08.2017].

16.Press, G., (2015): A Very Short History of Digitization. [online] Available at: <https://www.forbes.com/sites/gilpress/20 15/12/27/a-very-short-history-ofdigitization $>$ [Accessed 27.07.2017].

17.Richards, L., (2017): Factors affecting Organizational Behaviour, ehow [online]Available at: <http://www.ehow.com/info_8131521_fact ors-affecting-organizational-behavior.html>, [Accessed 28.08.2017].

18.Rinne, U. \& Zimmermann, K.F., (2016): Die Digitale Arbeitswelt von heute und Morgen, Aus Politik und Zeitgeschichte, (66/18-19), pp. 3-9.

19.Rouse, M., (2016a): Social Media. [online] Available

at: <http://whatis.techtarget.com/definition/ social-media> [Accessed 28.07.2017].

20.Rouse, M., (2016b): Cybersecurity. [online] Available at: <http://whatis.techtarget.com/definition/ cybersecurity> [Accessed 29.07.2017].

21.Rouse, M., (2017a): Big data analytics. [online] Available at: <http://searchbusinessanalytics. techtarget.com/definition/big-dataanalytics> [Accessed 28.07.2017].

22.Rouse, M., (2017b): Robotics. [online] Available at: <http://whatis.techtarget.com/definition/ robotics> [Accessed 28.07.2017].

23.Sattler, A., (2016): Leadership 4.0. [pdf] Available at: <http://zeitschriften.haufe.de/ePaper/ personalmagazin/2016/429B08E0/files/ass ets/common/downloads/publication.pdf> [Accessed 03.08.2017].

24.Schildt, H., (2017): Big data and organizational design - the brave new world of algorithmic management and computer augmented transparency, Innovation: organization \& Management, (19/1), pp. 2330.

25.Staab, P. and Nachtwey, O., (2016): Digitalisierung der Dienstleistungsarbeit, Aus Politik und Zeitgeschichte, (66/18-19), pp. 24-31

26. ***BMWi, (2016): Bechtle Magazin Zukunftsstark 2017. [pdf] Available at: $<$ https://www.bechtle-

update.com/assets/Digitalisierung2/InnovationLabs/bechtle_magazin_zukunftsstark_2017.p df> [Accessed 27.07.2017].

27.***Deloitte, (2017): Automate this - The business leader's guide to robotic and intelligent automation. [pdf] Available at: $<$ https://www2.deloitte.com/content/dam/ Deloitte/us/Documents/ 
process-and-operations/us-sdt-processautomation.pdf> [Accessed 28.07.2017].

28.***Ernst \& Young LLP, (2011): The digitisation of everything. [pdf] Available at: <http://www.ey.com/Publication/vwLUAss ets/The_digitisation_of_everything_-

_How_organisations_must_adapt_to_changin g_consumer_behaviour/\$FILE/EY_Digitisatio n_of_everything.pdf> [Accessed 27.07.2017].
29. ${ }^{* * *}$ ISA (n.d.): What Is Automation?. [online] Available at: <https://www.isa.org/about-isa/what-isautomation/> Accessed 28.07.2017].

30.**McKinsey, (2017): Smartening up with artificial intelligence. [online] Available at: <http://www.mckinsey.com/industries/sem iconductors/our-insights/smartening-upwith-artificial-intelligence $>$ [Accessed 28.07.2017]. 